\title{
Kinetics of progenitor hemopoetic stem cells in sepsis: Correlation with patients survival?
}

\author{
Thomas Tsaganos ${ }^{1}$, Evangelos J Giamarellos-Bourboulis*1, Spyridon Kollias ${ }^{2}$, \\ Dimitrios Zervakis ${ }^{2}$, Vassiliki Karagianni ${ }^{1}$, Aimilia Pelekanou${ }^{1}$, Ekaterini- \\ Christina Tampaki ${ }^{3}$, Marina Kontogiorgi ${ }^{2}$, Apostolos Koroneos ${ }^{2}$, \\ Nikolaos Drakoulis ${ }^{3}$, Apostolos Armaganidis ${ }^{4}$, Charis Roussos ${ }^{2}$ and \\ Helen Giamarellou ${ }^{1}$
}

\begin{abstract}
Address: ${ }^{1} 4$ th Department of Internal Medicine, University of Athens, Medical School, Greece, ${ }^{2} 1$ st Department of Critical Care, University of Athens, Medical School, Greece, ${ }^{3}$ Department of Pharmaceutical Technology, University of Athens, School of Pharmacy, Greece and ${ }^{4}$ nd Department of Critical Care, University of Athens, Medical School, Greece

Email: Thomas Tsaganos - tsag@freemail.gr; Evangelos J Giamarellos-Bourboulis* - giamarel@ath.forthnet.gr; Spyridon Kollias - croussos@med.uoa.gr; Dimitrios Zervakis - croussos@med.uoa.gr; Vassiliki Karagianni - basiliki96@hotmail.com; Aimilia Pelekanou - aimpelekanou@yahoo.gr; Ekaterini-Christina Tampaki - giamarel@ath.forthnet.gr; Marina Kontogiorgi - apo@hol.gr; Apostolos Koroneos - croussos@med.uoa.gr; Nikolaos Drakoulis - drakoulis@pharm.uoa.gr; Apostolos Armaganidis - aarmag@med.uoa.gr; Charis Roussos - croussos@med.uoa.gr; Helen Giamarellou - hgiama@ath.forthnet.gr

* Corresponding author
\end{abstract}

Published: 18 September 2006

BMC Infectious Diseases 2006, 6:142 doi:10.1/86/147|-2334-6-142
Received: 20 May 2006

Accepted: 18 September 2006

This article is available from: http://www.biomedcentral.com//47/-2334/6//42

(c) 2006 Tsaganos et al; licensee BioMed Central Ltd.

This is an Open Access article distributed under the terms of the Creative Commons Attribution License (http://creativecommons.org/licenses/by/2.0), which permits unrestricted use, distribution, and reproduction in any medium, provided the original work is properly cited.

\begin{abstract}
Background: Current theories underline the crucial role of pro-inflammatory mediators produced by monocytes for the pathogenesis of sepsis. Since monocytes derive from progenitor hemopoetic cells, the kinetics of stem cells was studied in peripheral blood of patients with sepsis.

Methods: Blood was sampled from 44 patients with septic syndrome due to ventilator-associated pneumonia on days I, 3, 5 and 7 upon initiation of symptoms. Concentrations of tumour necrosis factor-alpha (TNF $\alpha$ ), interleukin (IL)-6, IL-8 and G-CSF were estimated by ELISA. CD34/CD45 cells were determined after incubation with anti-CD45 FITC and anti-CD34 PE monocloncal antibodies and flow cytometric analysis. Samples from eight healthy volunteers served as controls.

Results: Median of CD34/CD45 absolute count of controls was I.0/ $\mu$ l. Respective values of the total study population were $123.4, I \mid 2.4, I 2 I .5$ and $I 20.9 / \mu \mid$ on days I, 3,5 and 7 ( $<<0.0001$ compared to controls). Positive correlations were found between the absolute CD34/CD45 count and the absolute monocyte count on days I, 5 and 7. Survival was prolonged among patients with less than $310 / \mu \mathrm{l} \mathrm{CD34/CD45}$ cells on day I compared to those with more than $310 / \mu \mathrm{l}$ of CD34/ CD45 cells (p: 0.022). Hazard ratio for death due to sepsis was 5.47 (p: 0.039) for CD34/CD45 cells more than $3 / 0 / \mu l$. Median IL-6 on day I was 56.78 and $233.85 \mathrm{pg} / \mathrm{ml}$ respectively for patients with less than $310 / \mu \mathrm{l}$ and more than $310 / \mu \mathrm{I} C D 34 / C D 45$ cells (p: 0.021 ).

Conclusion: Stem cells are increased in peripheral blood over all days of follow-up compared to healthy volunteers. Patients with counts on day I less than $310 / \mu \mathrm{I}$ are accompanied by increased survival compared to patients with more than $3 / 0 / \mu l$.
\end{abstract}




\section{Background}

Sepsis syndrome is one of the leading causes of death occurring in more than 1,500,000 patients each year in either Europe or North America with a mortality rate ranging between 35 and 50\% [1]. Current theory for pathogenesis is based on the production of pro-inflammatory mediators like tumour necrosis factor-alpha (TNF $\alpha$ ) and interleukins (IL) -6 and IL- 8 by cells of the innate immune system when triggered by constituents of bacterial cells of the responsible pathogens [2]. These cells of the innate immune system involved in pathogenesis are myeloid cells, mainly neutrophils and monocytes, derived from progenitor stem cells. During evolution of the septic process, increased apoptosis of monocytes and lymphocytes is observed $[3,4]$, leading to hypothesis that stem cells are activated through hemopoetic mechanisms in order to replace them. Despite the importance of stem cells for maturation into neutrophils and monocytes, no data are available in the current literature about the kinetics of stem cells in the peripheral blood of the septic host. Stem cells are recognized by the expression of the CD34 surface molecule on their cell membrane [5].

The present study aimed to provide information about stem cells circulating in blood in sepsis. In an attempt to apply a study population as homogenous as possible, only patients with ventilator-associated pneumonia and sepsis were enrolled in order to minimize confounding variables occurring when patients with different underlying infections offering a great variety of antigenic stimuli for the innate immune system were encountered together.

\section{Methods}

Study design

A total of 44 patients were enrolled in a prospective study that took place over the period May-November 2005. The study population was different than the one described recently [4]. Patients were hospitalized in the Department of Critical Care of the "Evangelismos" General Hospital and in the 2nd Department of Critical Care of the "ATTIKON" University Hospital of Athens. The study was approved by the Ethics Committee of both hospitals. All enrolled patients were intubated for at least 48 hours prior enrolment and they were aged above 18 years. Written informed consent was provided by their relatives.

Exclusion criteria were:

- any hematologic or solid tumor malignancy;

- any administration of G-CSF or CM-CSF over the last three months;

- neutropenia ( $\leq 500$ neutrophils $\left./ \mathrm{mm}^{3}\right)$;

\section{- HIV infection; and}

- oral intake of corticosteroids at a dose equal to or higher than $1 \mathrm{mg} / \mathrm{kg}$ equivalent of prednisone for a period greater than one month.

Inclusion criteria were the concomitant presence of:

- ventilator-associated pneumonia (VAP), and

- sepsis, severe sepsis or septic shock.

Death due to sepsis was the clinical endpoint of the study.

\section{Definitions}

Diagnosis of VAP was established in any patient presenting with the following signs:

- core temperature $>38^{\circ} \mathrm{C}$ or $<36^{\circ} \mathrm{C}$;

- new or persistent consolidation in lung X-ray;

- purulent trancheobronchial secretions (TBS);

- clinical pulmonary infection score (CPIS) more than 6 [6-9].

CPIS was determined after individual scoring for each of the following parameters [10], as follows:

- Core temperature $36.5-38.4^{\circ} \mathrm{C}$ : 0 points; $38.5-38.9^{\circ} \mathrm{C}$ : 1 point; $\leq 36{ }^{\circ} \mathrm{C}$ or $\geq 39^{\circ} \mathrm{C}: 2$ points

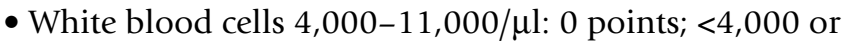
$>11,000 / \mu \mathrm{l}$ : 1 point; $>11,000$ points and more than $10 \%$ bands: 2 points

- $\mathrm{pO}_{2} / \mathrm{FiO}_{2} \geq 240$ or presence of ARDS: 0 points; $\mathrm{pO}_{2} / \mathrm{FiO}_{2}$ $<240$ in the absence of ARDS: 2 points

- Diffuse shadows on lung X-ray: 1 point; localized shadow on lung X-ray: 2 points

\section{- Purulent TBS: 2 points}

- TBS cultures yielding a pathogen $\geq 10^{6} \mathrm{cfu} / \mathrm{ml}$ with negative Gram stain: 1 point; TBS cultures yielding a pathogen $\geq 10^{6} \mathrm{cfu} / \mathrm{ml}$ with positive Gram stain: 2 points

Diagnosis of sepsis was based on the presence of at least two of the following [11]:

- core temperature $>38^{\circ} \mathrm{C}$ or $<36^{\circ} \mathrm{C}$;

- $\mathrm{P}_{\mathrm{CO} 2}<32 \mathrm{mmHg}$; 
- pulse rate $>90 / \mathrm{min}$; and

- white blood cells $>12,000 / \mu \mathrm{l}$ or $<4,000 / \mu \mathrm{l}$ or $>10 \%$ bands.

Severe sepsis was determined as the acute dysfunction of at least one organ i.e. the acute presentation of at least one of the following [11]:

- Acute Respiratory Distress Syndrome (ARDS), as any value of $\mathrm{pO}_{2} / \mathrm{FiO}_{2}$ below 200

- Acute renal failure, as the production of less than $0.5 \mathrm{ml} /$ $\mathrm{Kg}$ body weight/h of urine for at least two hours provided that the negative fluid balance of the patient was corrected

- Metabolic acidosis as any $\mathrm{pH}<7.30$ or any base deficit greater than $5 \mathrm{mEq} / \mathrm{l}$ and serum lactate at least more than $2 \times$ normal value

- Acute coagulopathy as any platelet count $<100.000 / \mu \mathrm{l}$ or INR $>1.5$

Septic shock was considered as any value of systolic pressure below $90 \mathrm{mmHg}$ requiring the administration of inotropic agents after adequate fluid resuscitation [11].

\section{Sample collection}

Upon enrolment in the study, quantitative cultures of tracheobronchial secretions (TBS) were performed; TBS were collected after insertion of a sterile catheter in the intubation tube or in the tracheotomy connected to a negative pressure device. Enrolled patients were followed-up on a daily basis for a total of 28 days; evaluation comprised lung X-rays, estimation of the $\mathrm{pO}_{2} / \mathrm{FiO}_{2}$ ratio and of the APACHE II and SOFA scores.

For the estimation of cytokines and of the percentage of CD34/CD45 cells, $5 \mathrm{ml}$ of blood were sampled after venipuncture of a peripheral vein under sterile conditions on the first, third, fifth and seventh days. Blood was collected into sterile tubes for the estimation of cytokines and into EDTA-coated tubes (Vacutainer, Becton Dickinson, Cockeysville $\mathrm{MD}$ ) for the determination of CD34/CD45 cells. After centrifugation, serum was kept at $-70^{\circ} \mathrm{C}$ until assayed.

\section{Laboratory techniques}

Cultures of TBS

Quantitative TBS cultures were performed immediately after collection; $0.5 \mathrm{ml}$ of sample were added into a sterile tube with $0.5 \mathrm{ml}$ of $1 \mathrm{mg} / \mathrm{ml}$ of dithiothreitol (Oxoid Ltd, London, UK) and diluted five consecutive times 1:10. Volumes of $0.1 \mathrm{ml}$ of each dilution were plated onto McConkey and blood agar (Becton Dickinson, Cockeysville,
$\mathrm{Md}$ ). Dishes were incubated for five days at $35^{\circ} \mathrm{C}$ and their count was estimated after multiplying with the appropriate dilution factor. Cultures yielding a pathogen at a count $\geq 1 \times 10^{6} \mathrm{cfu} / \mathrm{ml}$ were considered positive [10]. Identification of pathogens was performed by the API20E and the API20NE systems (bioMérieux, Paris L'Etoile, France).

\section{Serum cytokine measurements}

Concentrations of tumour necrosis factor-alpha (TNF $\alpha$ ), interleukin-6 (IL-6), and IL-8 in sera were estimated in duplicate by an enzyme immunoabsorbent assay (Diaclone, Paris, France). Lowest limits of detection were 0.5 $\mathrm{pg} / \mathrm{ml}$ for TNF $\alpha, 6.25 \mathrm{pg} / \mathrm{ml}$ for IL-6 and $62.5 \mathrm{pg} / \mathrm{ml}$ for IL-8. Concentrations of G-CSF (Granulocyte Colony Stimulating Factor) were estimated in sera of days 1 and 3 by an enzyme immunoabsorbent assay (R\&D Systems, Minneapolis, USA). Lowest limit of detection was $1.25 \mathrm{pg} / \mathrm{ml}$.

\section{Flow cytometric analysis of hemopoetic cells}

For the estimation of the percentage of CD34/CD45 cells, whole blood was applied. Red blood cells were lysed by the application of $\mathrm{NH}_{4} \mathrm{Cl} 0.1 \mathrm{M}$ and white blood cells were washed three times with PBS pH: 7.2. Subsequently, they were incubated for 15 minutes in the dark with the monoclonal antibodies anti-CD45 FITC (Immuotech, Marseille, France) and anti-CD34 PE (Immunotech). Cells staining positive for both CD34 and CD45 after analysis by the EPICS XL/MSL flow cytometer (Beckman Coulter Co) with gating for the whole cell population, were considered hemopoetic stem cells [2]. IgG FITC and IgG PE antibodies were applied as negative controls for each sample. Mean fluorescence intensity (MFI) was also recorded. In order to evaluate the percentage of CD34/ CD45 cells of the enrolled patient population, eight samples derived from healthy volunteers well matched for age and sex to the study population were applied. The absolute count of CD34/CD45 cells was estimated after multiplication of their percentage to the absolute white blood cell count determined after analysis by an automatic counter (Beckman Coulter Co).

\section{Statistical analysis}

Results were expressed as medians \pm standard errors (SE) or $95 \%$ confidence intervals (CI). Comparisons between patients and healthy controls were performed by the Mann-Whitney U test. Statistical correlations were performed after assessment of the non-parametric co-efficient of Spearman $\left(r_{s}\right)$. Survival Kaplan-Meier analysis was performed separately for patients with CD34/CD45 cells less than $310 / \mu \mathrm{l}$ and equal to or more than $310 / \mu \mathrm{l}$. The latter threshold was applied after scatterploting of single values of survivors and non-survivors. Survival curves were compared by the log-rank test. Cox regression analysis for estimation of hazard risk (HR) and their 95\%CI for 
death due to sepsis was performed; APACHE II score of day 1 more than 20, category of critical illness and the count of CD34/CD45 cells on day 1 were covariates. Changes of CD34/CD45 counts were estimated between days 1 and 3, between days 1 and 5 and between days 1 and 7 . These changes were compared for patients with CD34/CD45 cells less than $310 / \mu \mathrm{l}$ and equal to or more than $310 / \mu$ l on day 1 by the Mann-Whitney U test. Any value of p below 0.05 was considered statistically significant.

\section{Results}

Clinical characteristics of patients enrolled in the study are shown in Table 1. Median \pm SE of CD34/CD45 cells of controls was $1.0 \pm 3.2 / \mu$ l. Respective values of the total study population were $123.4 \pm 61.6,112.4 \pm 96.8,121.5$ \pm 96.8 and $120.9 \pm 30.6 / \mu \mathrm{l}$ on days $1,3,5$ and 7 of followup respectively ( $\mathrm{p}$ of comparisons of all days to controls less than 0.0001). In these days median \pm SE of MFI were $6.05 \pm 0.33,6.55 \pm 0.33,6.10 \pm 0.58$ and $6.15 \pm 0.55$ respectively. Follow-up values of CD34/CD45 cells separately for patients with sepsis, severe sepsis and septic shock are shown in Figure 1.

Median \pm SE of neutrophils of the whole study population on days $1,3,5$ and 7 were $8,303.8 \pm 1,064.8,8,683.4 \pm$ $1,051.4,8,748.4 \pm 1,086.6$ and $7.659 .4 \pm 919.9 / \mu 1$ respec-

Table I: Demographic characteristics of 44 patients with ventilator-associated pneumonia (VAP) and sepsis enrolled in the study.

\begin{tabular}{|c|c|}
\hline Age (years, mean $\pm S D$ ) & $59.56 \pm 18.28$ \\
\hline Male/Female & $32 / 12$ \\
\hline APACHE II score (mean \pm SD) & $16.49 \pm 5.52$ \\
\hline SOFA score $($ mean \pm SD) & $8.14 \pm 3.39$ \\
\hline White blood cells (mean $\pm S D, / \mu \mathrm{l})$ & $12,939.8 \pm 6,502.5$ \\
\hline Sepsis [No of patients (\%)] & $10(22.72)$ \\
\hline Severe Sepsis [No of patients (\%)] & $12(27.27)$ \\
\hline Septic shock [No of patients (\%)] & $22(50.00)$ \\
\hline \multicolumn{2}{|l|}{ Underlying conditions [No (\%)] } \\
\hline Multiple injuries & $10(22.72)$ \\
\hline Chronic obstructive pulmonary disease & $22(50.00)$ \\
\hline Celiac aortic aneurysm replacement & $5(11.36)$ \\
\hline Others & $5(11.36)$ \\
\hline \multicolumn{2}{|l|}{ Predisposing factors [No (\%)] } \\
\hline Diabetes mellitus 2 & $7(15.91)$ \\
\hline Coronary Heart Disease & $10(22.72)$ \\
\hline Others & $5(11.36)$ \\
\hline Positive cultures of TBS* [No (\%)] & $25(56.82)$ \\
\hline Acinetobacter baumannii & 15 (34.09) \\
\hline Pseudomonas aeruginosa & $7(15.91)$ \\
\hline Others & $3(6.82)$ \\
\hline
\end{tabular}

*Tracheobronchial secretions

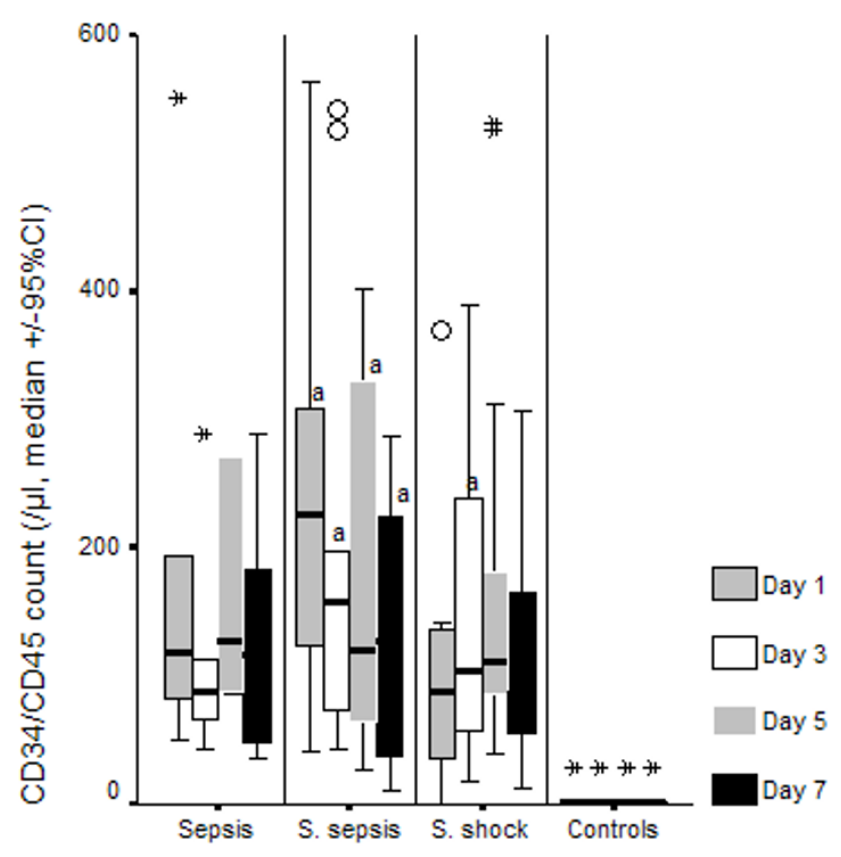

Figure I

Absolute blood counts of CD34/CD45 cells over daily follow-up of patients with ventilator-associated pneumonia (VAP) and sepsis, severe sepsis or septic shock. Circles denote outliers and asterisks denote extremes. ${ }^{\mathrm{a}} \mathrm{p}<0.05$ compared to sepsis.

tively. No correlation was found between the absolute CD34/CD45 count and the absolute neutrophil count of patients in any day of follow-up. Median \pm SE of monocytes of the whole study population on days $1,3,5$ and 7 were $630.3 \pm 64.0,585.5 \pm 76.9,632.9 \pm 112.7$ and 568.2 $\pm 99.4 / \mu$ l respectively. Positive correlations were found between the absolute CD34/CD45 count and the absolute monocyte count on day $1\left(\mathrm{r}_{\mathrm{s}}:+0.342, \mathrm{p}: 0.031\right)$, on day 5 $\left(r_{s}:+0.402, p: 0.015\right)$ and on day $7\left(r_{s}:+0.359, p: 0.034\right)$.

Death from all causes supervened in 12 patients (27.27\%); death attributed to the initial septic episode that lead to study enrolment occurred in eight patients (18.18\%). Survival curves for patients with absolute count of CD34/CD45 cells on the first day less than $310 / \mu \mathrm{l}$ and equal to or more than $310 / \mu \mathrm{l}$ are shown in Figure 2. Survival was prolonged among patients with less than $310 / \mu \mathrm{l}$ (p: 0.022). Representative flow plots of the expression of CD34 on two patients, one with less than $310 / \mu \mathrm{l}$ CD34/ CD45 cells on day 1 and another with more than $310 / \mu$ l CD34/CD45 cells on day 1, are given in Figure 3.

Median \pm SE changes of CD34/CD45 counts between days 1 and 3 were $-2.7 \pm 25.8$ and $+260.4 \pm 284.8 / \mu l$ for patients with CD34/CD45 cells less than $310 / \mu \mathrm{l}$ and equal to or more than $310 / \mu \mathrm{l}$ on day 1 respectively (p: 


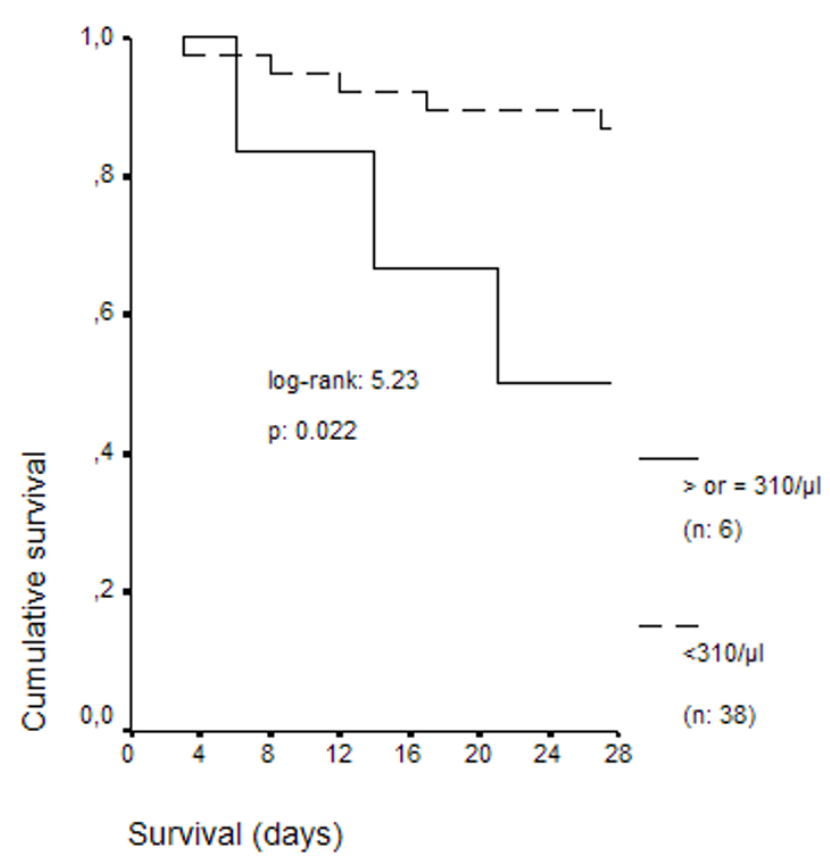

Figure 2

Survival curves of 44 patients with ventilator-associated pneumonia (VAP) and sepsis in relation to the absolute blood count of CD34/CD45 cells on the first day of diagnosis.

A)

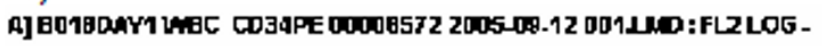

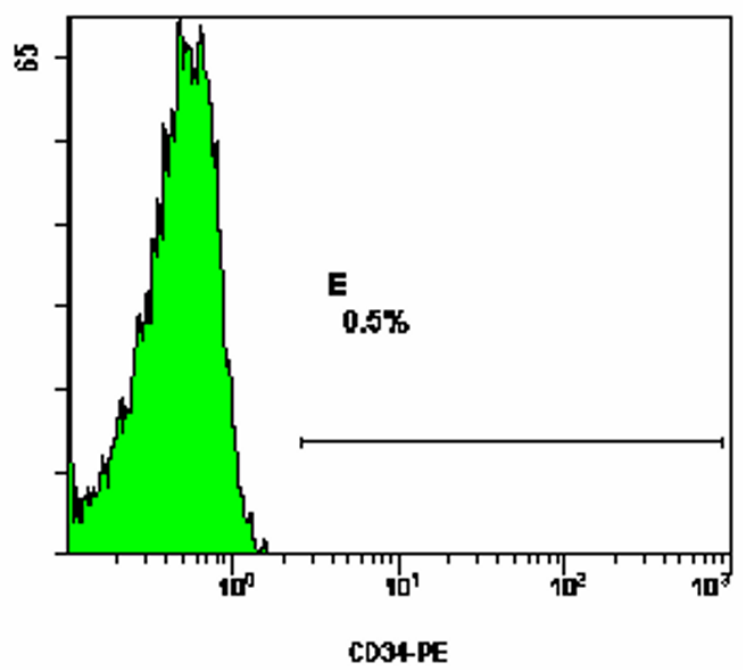

$0.011)$. Respective values of changes between days 1 and 5 were $-41.9 \pm 111.4$ and $231.4 \pm 256.9 / \mu l(p N S)$ and between day 1 and $712.2 \pm 19.23$ and $366.1 \pm 311.2 / \mu \mathrm{l}$ (p: 0.004).

HR for death due to sepsis was 4.49 (pNS, 95\%CI: 0.9122.108) for APACHE II more than 20, 2.19 (pNS, 95\%CI: 0.50-9.57) for category of critical illness and 5.47 (p: 0.027, 95\%C: 1.21-24.65) for CD34/CD45 cells $\geq 310 / \mu l$.

Median \pm SE TNF $\alpha$ of the whole study population on days $1,3,5$ and 7 were $9.12 \pm 2.17,10.02 \pm 3.30,9.724 \pm 35.41$ and $8.61 \pm 18.92 \mathrm{pg} / \mathrm{ml}$ respectively. Median \pm SE IL-6 of the whole study population on days 1, 3, 5 and 7 were $67.86 \pm 19.89,66.62 \pm 14.89,57.14 \pm 14.79$ and $59.15 \pm$ $13.41 \mathrm{pg} / \mathrm{ml}$ respectively. Median \pm SE IL-8 of the whole study population on days $1,3,5$ and 7 were $112.5 \pm$ $156.8,62.5 \pm 282.1,275.6 \pm 165.0$ and $125.0 \pm 96.1 \mathrm{pg} /$ ml respectively. Median \pm SE G-CSF of the whole study population on days 1 and 3 were $78.13 \pm 53.75$ and 73.21 $\pm 60.56 \mathrm{pg} / \mathrm{ml}$ respectively. Lack of any correlation was noted between CD34/CD45 absolute counts and serum levels of TNFo, IL-6, IL-8 and G-CSF on each day of follow-up.

Median \pm SE TNF $\alpha$ on day 1 were $9.54 \pm 2.45$ and $21.33 \pm$ $6.55 \mathrm{pg} / \mathrm{ml}$ respectively for patients with less than $310 / \mu \mathrm{l}$

B)

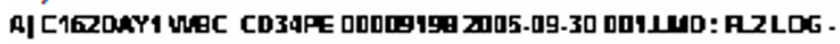

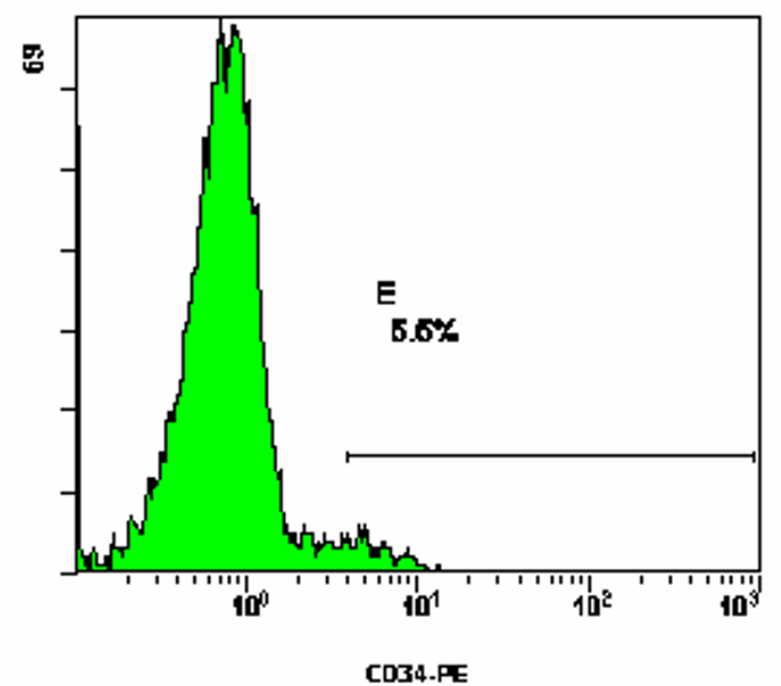

Figure 3

Flow plots of the expression of CD34 in two patients with ventilator-associated pneumonia (VAP) and sepsis on day I; patient A with $180 / \mu$ l CD34/CD45 cells and patient B with I,737/ $\mu$ I CD34/CD45 cells. 
and equal to or more than $310 / \mu \mathrm{l}$ CD34/CD45 cells (pNS). Respective values for IL-6 were $56.78 \pm 22.16$ and $233.85 \pm 67.87 \mathrm{pg} / \mathrm{ml}$ (p: 0.021 ); for IL-8 were $71.3 \pm 111$. 9 and $62.5 \pm 105.2 \mathrm{pg} / \mathrm{ml}$ (pNS); and for G-CSF were $78.12 \pm 64.41$ and 78.12 $\pm 71.99 \mathrm{pg} / \mathrm{ml}$ (pNS).

\section{Discussion}

Current theories for the pathogenesis of sepsis implicate the dominant role of cells of the innate immune system i.e. monocytes and neutrophils for the biosynthesis of pro-inflammatory mediators after triggering by bacterial pathogens [2]; these mediators elicit further clinical signs of the septic host. Neutrophils and monocytes constitute myeloid cells derived from progenitor hemopoetic stem cells that are CD34/CD45-positive cells [5]. Based on the hypothesis that white blood cells die through apoptosis in sepsis $[3,4]$, stem cells may be triggered for further expansion. Since no data are available in the current literature, the present study was assigned to the kinetics of progenitor stem cells in the peripheral circulation of septic patients.

Results revealed that the percentage of stem cells in blood of septic patients was higher than in healthy volunteers, a phenomenon observed for all the first seven days of follow-up. The latter finding was particularly pronounced in the event of severe sepsis (Figure 1).

The most important finding of the present study was the existence of a correlation between CD34/CD45 count of day 1 and the patients' outcome. Time of survival was decreased for patients with stem cells equal to or more than $310 / \mu$ in their blood compared to patients with stem cells less than $310 / \mu$ l (Figure 2). That finding was further verified by Cox regression analysis revealing that presence of $\geq 310 / \mu$ l stem cells was accompanied by a significantly increased risk of death of 5.47 times more than in patients with less than $310 / \mu \mathrm{l}$ stem cells. No data are available in the literature that may explain the described correlation between the level of stem cells in blood and time of survival. As a consequence, only hypotheses can be made. Based on the detected positive correlation between CD34/CD45 counts and monocytes counts, it might be presumed that increased progenitor cells would give rise to increased hemopoesis of monocytes and to subsequent augmented burden of pro-inflammatory mediators. It was of striking importance to show that in patients with CD34/CD45 higher than $310 / \mu$ on day 1 , their counts fell on the consecutive days underlying the importance of increased hemopoesis of day 1 for the outcome of the patient.

The search for the impact of circulating pro-inflammatory cytokines on the count of stem cells, showed that circulating levels of IL- 6 were higher on day 1 among patients with CD34/CD45 higher than $310 / \mu \mathrm{l}$ compared to patients with less than $310 / \mu \mathrm{l}$. A similar difference was not detected for TNF $\alpha$, IL-8 or G-CSF. The importance of IL-6 for triggering of hemopoesis on day 1 might be supported from in vitro evidence describing IL-6 as a promoter of the expansion of progenitor hemopoetic cells $[13,14]$.

The above results are strengthened in the light of a study population being as homogenous as possible. All enrolled patients became septic by the same underlying infection i.e. VAP. That study design allowed to elaborate a similar antigenic stimulus to the immune system of all patients concerning the infective focus. Analysis revealed that patients were predominantly infected by species of Pseudomonas aeruginosa and by Acinetobacter baumannii (Table 1) so that the offered bacterial triggering to the entire population was the most homogenous possible.

\section{Conclusion}

This is the first study in the literature, describing the kinetics of stem cells in the septic process. They are increased over all days of follow-up compared to healthy volunteers and they are positively correlated to absolute monocyte counts. Moreover their count on day 1 is correlated to time of survival since patients with less than $310 / \mu$ l survived longer compared to patients with equal to or more than $310 / \mu$ l. The latter data might unravel a novel pathophysiological pathway that although that may not be applied directly in clinical practice, their importance is enormous since all novel therapies for the septic host are targeting the pathogenetic cascade.

\author{
Abbreviations \\ TNFo: tumour necrosis factor-alpha \\ IL-6: interleukin-6 \\ IL-8: interleukin-8 \\ G-CSF: granulocyte colony stimulating factor
}

\section{Competing interests}

The author(s) declare that they have no competing interests.

\section{Authors' contributions}

TT participated in the design of the study, in the estimation of inflammatory parameters and drafted the manuscript.

EJGB participated in the design of the study and drafted the manuscript.

SK participated in the enrolment of patients. 
DZ participated in the enrolment of patients.

VK participated in flow cytometric analysis

AP participated in the estimation of G-CSF

ET participated in performance of total white cell counts and cytokines

MK participated in the enrolment of patients.

AK participated in the enrolment of patients.

ND drafted the manuscript

AA drafted the manuscript

CR drafted the manuscript

HG participated in study design and drafted the manuscript

All authors have read and approved the final manuscript

\section{Acknowledgements}

This study was supported by an unrestricted educational grant by Abbott Laboratories Hellas SA.

\section{References}

I. Annane D, Aegerter P, Jars-Guincestre C, Guidet B: Current epidemiology of septic shock. Am J Resp Crit care Med 2003, 168:165-172.

2. Abraham E: Nuclear factor- $\kappa B$ and its role in sepsis-associated organ failure. J Infect Dis 2003, 187(Suppl 2):S364-S369.

3. Hotchkiss RS, Osmon SB, Chang KC, Wagner TH, Coopersmith CM, Karl IE: Accelerated lymphocyte death in sepsis occurs by both the death receptor and mitochondrial pathways. J Clin Oncol 2005, 174:5।I0-5।I8.

4. Giamarellos-Bourboulis EJ, Routsi C, Plachouras D, Markaki V, Raftogiannis $M$, Zervakis D, Koussoulas V, Orfanos S, Kotanidou A, Armaganidis $\mathrm{A}$, Roussos $\mathrm{C}$, Giamarellou $\mathrm{H}$ : Early apoptosis of blood monocytes in the septic host: is it a mechanism of protection in the event of septic shock? Crit Care 2006, 10:R76.

5. Lynch L, O'Donoghue D, Dean J, O'Sullivan J, O'Farrelly C, GoldenMason L: Detection and characterization of hemopoeitic stem cells in the adult human small intestine. J Immunol 2006, I 76:5199-5204.

6. Michel F, Franceschini B, Berger P, Arnal JM, Gainnier M, Sainty JM, Papazian $L$ : Early antibiotic treatment for BAL-confirmed ventilator-associated pneumonia. A role for routine endotracheal aspirate cultures. Chest 2005, 127:589-597.

7. Chastre J, Fagon JY: Ventilator-associated pneumonia. $\mathrm{Am} J$ Respir Crit Care Med 2002, 165:867-903.

8. Rello J, Paiva JA, Baraibar J, Barcenilla F, Bodi M, Castander D, Correa H, Diaz E, Garnacho J, Llorio M, Rios M, Rodriguez A, Sole-Violan J: International conference for the development of consensus on the diagnosis and treatment of ventilator-associated pneumonia. Chest 200I, 120:955-970.

9. Baughman RP: Diagnosis of ventilator-associated pneumonia. Curr Opin Crit Care 2003, 9:397-402.

10. Pugin J, Auckenthaler R, Mili N, Janssens JP, Lew PD, Suter PM: Diagnosis of ventilator-associated pneumonia by bacteriologic analysis of bronchoscopic and nonbronchoscopic "blind" bronchoalveolar lavage fluid. Am Rev Respir Dis 199I, | 43: 1| $21-1 \mid 29$.
II. Levy M, Fink MP, Marshall JC, Abraham E, Angus D, Cook D, Cohen J, Opal SM, Vincent JL, Ramsay G: 200 I SCCM/ESICM/ACCPI ATS/SIS international sepsis definitions conference. Crit Care Med 2003, 31: | 250-। 256.

12. Camargo LFA, De Marco FV, Barbas CSV, Hoelz C, Bueno MAS, Rodrigues M Jr, Amado VM, Caserta R, Dalla Valle Martino M, Pasternak J, Knobel E: Ventilator associated pneumonia: comparison between quantitative and qualitative cultures of tracheal aspirates. Crit Care 2004, 8:R422-R430.

13. Encabo A, Solves P, Mateu E, Sepúlveda P, Carbonell-Uberos F, Miòana MD: Selective generation of different dendritic cell precursors from CD34+ cells by interleukin-6 and interleukin-3. Stem Cells 2003, 22:725-740.

14. Sanchez Garcia J, Torres A, Herrera C, Alvarez MA: Cell cycle kinetic changes induced by interleukin-3 and interleukin- 6 during ex vivo expansion of mobilized peripheral blood CD34 cell. Haematologica 2006, 9 I: I2I-I24.

\section{Pre-publication history}

The pre-publication history for this paper can be accessed here:

http://www.biomedcentral.com/1471-2334/6/142/pre pub

Publish with BioMed Central and every scientist can read your work free of charge

"BioMed Central will be the most significant development for disseminating the results of biomedical research in our lifetime. "

Sir Paul Nurse, Cancer Research UK

Your research papers will be:

- available free of charge to the entire biomedical community

- peer reviewed and published immediately upon acceptance

- cited in PubMed and archived on PubMed Central

- yours - you keep the copyright

BioMedcentral 